\title{
Effect of Sulphur Levels on Grain Yield of Clusterbean [Cyamopsis tetragonoloba (L.) Taub.] under Rainfed Condition in Hanumangarh District of Rajasthan, India
}

\author{
Akshaya Ghintala*, Bheiru Singh, Mukesh Kumar Verma, Anjali Sharma and \\ Manohar Lal Sain
}

Krishi Vigyan Kendra, Nohar, Hanumangarh-II (Raj.), India

*Corresponding author

A B S T R A C T

\begin{tabular}{|l|}
\hline Ke y w or d s \\
On Farm Trials, Sulphur \\
level, Cluster-bean
\end{tabular}

\section{Introduction}

Clusterbean is an important arid legume crop locally known as 'Guar' belongs to the family Leguminoseae and sub-family Papilonaceae. Gillete (1958) reported 'Tropical Africa' as its center of origin. Botanically Cluster bean is known as Cyamopsis tetragonoloba (L.) Taub.

The name gaur means gau ahar which indicates rich meal for cattle. It is an important rainy season drought resistant leguminous crop suited to dry farming areas and grown extensively on dry land of India. However, it cannot with stand under excessive moisture or water logging condition. Any improvement
A field experiment was conducted to investigate the effect of sulphur levels on grain yield of clusterbean on the yield attributes of clusterbean in Hanumangarh District of Rajasthan. Result showed that the assessed technology of T3- Soil application of sulphur @ 40 kg per hectare recorded highest average grain yield (10.37 qtl/ha) and highest average net returns (Rs. 27,013 per ha) as compared to T2- Soil application of sulphur @ $20 \mathrm{~kg}$ per hectare and farmers practice. But T2- Soil application of sulphur @ $20 \mathrm{~kg}$ per hectare recorded highest average B: C ratio (3.23) as compared to T3- Soil application of sulphur @ $40 \mathrm{~kg}$ per hectare and farmers practice. The trials also built the relationship and confidence between farmers and scientist of Krishi Vigyan Kendra. Therefore, it is suggested that these factors may be taken care to increase the scientific temperament of the farmers.

brought about in the quality of crop will go long way deciding the future of this crop in India. The area under cluster bean seed production in India is about 2.95 million hectares with the production of 10.59 million tones with average productivity of $418.49 \mathrm{~kg}$ per hectare (Meena et al., 2006). In India the state of Rajasthan, Haryana, Gujarat, Punjab and Uttar Pradesh are known to be the leading states for cultivation of cluster bean. Rajasthan contributed $70 \%$, Haryana $12 \%$, Gujarat $11 \%$, Punjab $3 \%$ and other $4 \%$ of the total production in India (Anonymous, 2006-07).

Fertilizer is a kingpin to increase agriculture production. In India, during past three to four 
decades, the use of fertilizers have been recognized as the most effective input for higher crop production to varieties and irrigation. Optimum fertilizer application is one of the well-established techniques for increase in crop productivity. Sulphur is now recognized as the fourth ranked nutrient followed by nitrogen, phosphorus and potash. It is also needed in large amount by pulse crops (Saraf, 1988). It's deficiency in India is widely spread particularly in high intensive cropping system. Sulphur is essential for synthesis of protein formation of chlorophyll and glycosides and nutritive quality of forages; vitamins and sulphur containing essential amino acids viz., methionine (21\%), cystine (27) (Singh et al., 2004). Sulphur also markedly enhanced the content of phosphorus, sulphur and gum in grain. Phosphorus and sulphur are reported to have synergistic effect on productivity of crops (Singh and Ram, 1989).

Keeping above facts in view, the present investigation was taken to study the "Effect of sulphur levels on grain yield of Clusterbean [Cyamopsis tetragonoloba (L.) Taub.] under Rainfed condition in Hanumangarh District of Rajasthan".

\section{Materials and Methods}

Present study was conducted in 26 locations of Hanumangarh district of Rajasthan by Krishi Vigyan Kendra, Nohar, Hanumangarh-II during kharif 2013-14 to 2015-16 (three consecutive years) for productivity enhancement of Clusterbean under On Farm Testing. There were 3 treatments i.e. T1Farmers practice (No use of sulphur), T2 Soil application of sulphur @ $20 \mathrm{~kg}$ per hectare and T3 - Soil application of sulphur @ $40 \mathrm{~kg}$ per hectare. Each treatment conducted in 0.25 hectare area $(0.75$ hectare area per trial). Parameter of assessment was grain yield.

\section{Results and Discussion}

\section{Performance of OFTs (On Farm Trials)}

The finding of the study revealed that the assessed technology of use of sulphur grain yield was increased of clusterbean (Table 1). Result showed that the assessed technology of T3: Soil application of sulphur @ $40 \mathrm{~kg}$ per hectare highest average grain yield was recorded (10.37 qtl/ha) as compared to average yield T2- Soil application of sulphur @ $20 \mathrm{~kg}$ per hectare (10.04 qtl/ha) and farmers practice (8.54 qtl/ha).

\section{Economic analysis of OFTs (On Farm Trials)}

The economics of clusterbean production under trials were estimated and the results of the study have been presented in Table 2 . The results of economic analysis of clusterbean production revealed that T3- Soil application of sulphur @ $40 \mathrm{~kg}$ per hectare a highest average net returns was recorded of Rs. 27,013 per ha as compared to T2- Soil application of sulphur@ $@ 20 \mathrm{~kg}$ per hectare practice (Rs.26,873 per ha) and farmers practice (Rs.20,253 per ha).

But T2- Soil application of sulphur @ 20 kg per hectare was recorded highest average benefit cost ratio (3.32) as compared to T3Soil application of sulphur @ $40 \mathrm{~kg}$ per hectare (3.23) and farmers practice (2.82).

The present investigation was taken to study the effect of sulphur levels on grain yield of clusterbean. The finding of the study revealed that the assessed technology of T3: Soil application of sulphur@ @ $40 \mathrm{~kg}$ per hectare highest average grain yield was recorded (10.37 qtl/ha) as compared to average yield T2- Soil application of sulphur @ $20 \mathrm{~kg}$ per hectare (10.04 qtl/ha) and farmers practice (8.54 qtl/ha). 
Table.1 Performance of OFTs on "Effect of sulphur levels on grain yield of clusterbean"

\begin{tabular}{|c|c|c|c|c|c|}
\hline \multirow[t]{2}{*}{ S. N. } & \multirow[t]{2}{*}{ Treatment } & \multicolumn{4}{|c|}{ Grain Yield (qtl/ha) } \\
\hline & & 2013-14 & 2014-15 & 2015-16 & Average \\
\hline 1 & T1: Farmers practice (No use of sulphur) & 9.33 & 10.50 & 5.80 & 8.54 \\
\hline 2 & T2: Soil application of sulphur @ $20 \mathrm{~kg}$ per hectare & 11.25 & 12.38 & 6.50 & 10.04 \\
\hline 3 & T3: Soil application of sulphur @ 40 kg per hectare & 11.40 & 12.50 & 7.20 & 10.37 \\
\hline
\end{tabular}

Table.2 Economic analysis of OFTs on "Effect of sulphur levels on grain yield of Clusterbean"

\begin{tabular}{|c|c|c|c|c|c|c|c|}
\hline \multicolumn{4}{|c|}{ Net return (Profit) in Rs./ha } & \multicolumn{4}{c|}{ B:C ratio } \\
\hline $\mathbf{2 0 1 3 - 1 4}$ & $\mathbf{2 0 1 4 - 1 5}$ & $\mathbf{2 0 1 5 - 1 6}$ & Average & $\mathbf{2 0 1 3 - 1 4}$ & $\mathbf{2 0 1 4 - 1 5}$ & $\mathbf{2 0 1 5 - 1 6}$ & A verage \\
\hline $\mathbf{1 9 , 6 5 0}$ & 31,000 & 10,110 & 20,253 & 1.72 & 3.82 & 2.93 & $\mathbf{2 . 8 2}$ \\
\hline $\mathbf{2 7 , 4 5 0}$ & 37,920 & 15,250 & 26,873 & 1.95 & 4.27 & 3.75 & $\mathbf{3 . 3 2}$ \\
\hline $\mathbf{2 6 , 4 0 0}$ & $\mathbf{3 7 , 8 0 0}$ & $\mathbf{1 6 , 8 4 0}$ & $\mathbf{2 7 , 0 1 3}$ & 1.86 & 4.10 & 3.72 & $\mathbf{3 . 2 3}$ \\
\hline
\end{tabular}

The results of economic analysis of clusterbean production revealed that T3- Soil application of sulphur @ $40 \mathrm{~kg}$ per hectare a highest average net returns was recorded of Rs. 27,013 per ha as compared to T2- Soil application of sulphur @ $20 \mathrm{~kg}$ per hectare practice (Rs.26,873 per ha) and farmers practice (Rs.20,253 per ha). But T2- Soil application of sulphur @ $20 \mathrm{~kg}$ per hectare was recorded highest average benefit cost ratio (3.32) as compared to T3- Soil application of sulphur @ $40 \mathrm{~kg}$ per hectare (3.23) and farmers practice (2.82).

The Trials also built the relationship and confidence between farmers and scientist of Krishi Vigyan Kendra. Therefore it is suggested that these factors may be taken for considered to increase the scientific temperament of the farmers.

\section{References}

Anonymous (2006-07). www.nmce.com, National Multi-commodity exchange of India.

Anonymous, (2013-14 to 2015-16). Annual Progress Report, Krishi Vigyan Kendra, Nohar, Hanumangarh-II.
Bhadoria, R. B. S., Tomar, R. A. S., Khan, H. and Sharma, M. K. (1997). Effect of phosphorus and sulphur on yield and quality of clusterbean \{Cyamopsis tetragonoloba (L.) Taub.\} Indian J. Agron. 42 (1): 131-134.

Gillete, S. T. (1958). Indigotera in tropical Africa with related genera Cyamopsis and Ryncotropis. Kew bull. Addition Ser., 1: 1- 66.

Kuniya, N., Chaudhary, N. and Patel, S. (2018). Effect of sulphur and zinc application on growth, yield attributes, yield and quality of summer Clusterbean [Cyamopsis tetragonoloba (L.)] in light textured soil. Inter. J. of Chemical Studies, 6(1): 1529-1532.

Meena, K.R., Dhamma, A.K. and Reager, M.L. (2006). Effect of phosphorus ans zinc fertilization on growth and quality of cluster bean. \{Cyamopsis tetragonoloba (L.) Taub\}. Annals of Agricultural Research. 27(3): 224-226.

Rooge, R. B., Patil, V. C. and Ravikishan, P. (1998). Effect of phosphorus application with phosphate solubilizing organism on the yield, quality and Puptake of soyabean. Legume Research, 21(2): 85-90. 
Saraf, A. P. (1988). Sulphur fertilization for yield and quality (In) processing of the TSI-FAI symposium on sulphur in Indian Agriculture, held at New Delhi, India, during 9th - 11th March, 1988, 2: 1-7.

Singh, R. V. and Singh, R. R. (1989). Effect of nitrogen, phosphorus and seedling rates on growth, yield and quality of Guar under rainfed conditions. Indian $J$. Agron. (1):53-56.
Singh, S., Saini, S.S. and Singh, B.P. (2004). Effect of irrigation, sulphur and seed inoculation on growth, yield and sulphur uptake of chickpea (Cicer arietinum) under late-sown conditions. Indian J. Agron.49 (1):57-59.

Whyte, R. O., Leissner, G. N. and Trumble, H. C. (1953). Legumes in Agriculture, FAO, Agric. Studies, No.21 Pp: 367.

\section{How to cite this article:}

Akshaya Ghintala, Bheiru Singh, Mukesh Kumar Verma, Anjali Sharms and Manohar Lal Sain. 2018. Effect of Sulphur Levels on Grain Yield of Clusterbean [Cyamopsis tetragonoloba (L.) Taub.] under Rainfed Condition in Hanumangarh District of Rajasthan, India. Int.J.Curr.Microbiol.App.Sci. 7(10): 2525-2528. doi: https://doi.org/10.20546/ijcmas.2018.710.293 